\title{
Network brokers or hit makers? Analyzing the influence of incubation on start-up investments
}

\author{
Frank J. Van Rijnsoever ${ }^{1}$ - Marijn A. Van Weele ${ }^{1}$. \\ Chris P. Eveleens ${ }^{1}$
}

Published online: 24 October 2016

(C) The Author(s) 2016. This article is published with open access at Springerlink.com

\begin{abstract}
Incubators are a prominent way to support technology based start-ups. Yet, it remains unclear to what extent these incubators enhance start-up performance, nor is it known through which mechanisms this would occur. In this paper we test two mechanisms to explain the relationship between incubation and the amount of investments raised by early stage start-ups as performance measure. The 'hit maker' mechanism refers to beneficial effects of the direct transfer of resources and organizational or business knowledge from the incubator to the start-up. The 'network broker' mechanism refers to the benefits that start-ups enjoy from being connected to external funding sources through the incubator's networks. We test which of these mechanisms contribute to the performance of early stage start-ups. Our data comes from a unique survey from 935 entrepreneurs with early-stage technology based start-ups in Western Europe and North America. We find that incubators have a positive effect on (1) the amount of funding that start-ups attract and (2) the ability of start-ups to attract funding from formal investors and banks. Moreover, our results provide evidence for the network broker mechanism, but not for the hit maker mechanism.
\end{abstract}

Keywords Entrepreneurship · Incubators · Networks · Direct support · Investments

\section{Introduction}

Incubators are one of the most prominent means to support early-stage technologybased start-ups (Ahmad and Ingle 2013; Bergek and Norrman 2008; Oakey 2012). Incubators aim to facilitate the survival and growth of these start-ups by providing them

Frank J. Van Rijnsoever

f.j.vanrijnsoever@uu.nl

1 Innovation studies, Copernicus Institute of sustainable development, Utrecht University, Heidelberglaan 2, 3528 Utrecht, CS, Netherlands 
with a comprehensive range of services, such as shared office space, specialized knowledge, and a network of clients and investors (Bergek and Norrman 2008; Hackett and Dilts 2004). Still, it remains unclear whether these potential benefits also translate into greater start-up performance. Whereas some studies suggest that incubators have a positive impact on the performance of start-ups (Stokan et al. 2015), others have found the impact of incubators to be nonexistent (Tamásy 2007; Westhead and Storey 1994) or even negative (Schwartz 2013). These contradictory findings have been ascribed to several challenges associated with measuring the performance of incubators, which include limited availability of data (see e.g. Barbero et al. 2012; Colombo and Delmastro 2002; Schwartz 2013; Stokan et al. 2015), inconsistent use of performance measures (Bergek and Norrman 2008; Hackett and Dilts 2004; Schwartz 2013), and sample selection biases (Aerts et al. 2007; Schwartz 2008).

A more fundamental challenge is to identify the theoretical mechanisms through which incubators contribute to the success (or failure) of start-ups. Measuring the incubator's impact on start-up performance has little value if studies are not able explain how incubators make such an impact (Ahmad 2014; Hackett and Dilts 2004). The literature identifies two distinct theoretical mechanisms that explain the incubator's impact on start-up performance: direct support and networking (Amezcua et al. 2013; Bergek and Norrman 2008; Patton 2013).

Direct support refers to the direct transfer of resources from the incubator to the startup. These can be tangible resources like office space or funding, but also intangible resources like business knowledge that is transferred with help of experienced incubator managers, coaches, pitching training sessions, and workshops (Van Weele et al. 2016a). By using these support services, incubators can directly improve start-up performance, and can thus be seen as "hit makers".

The networking mechanism refers to the activities of incubators to improve a start-up's network, for example by providing referrals or organizing networking events (Bøllingtoft and Ulhøi 2005; Collinson and Gregson 2003; Warren et al. 2009). These services help start-ups to acquire the necessary social capital to gain access to resources in the incubator's network that enhance performance (Davidsson and Honig 2003). Through this mechanism, the incubator serves as a "network broker".

In this paper, we study which of these two mechanisms contribute to the performance of early-stage technology-based start-ups. Our data come from a unique survey of 935 entrepreneurs who founded early-stage technology-based start-ups in Western Europe and North America. We measure performance as the monetary amount of investments raised by the start-up, as this has a high signaling value for future performance (De Clercq et al. 2006; Rothaermel and Thursby 2005; Vohora et al. 2004). By studying the combined interaction effect between incubation and the use of different funding sources, we explore whether the two mechanisms explain start-up performance. We find that incubators have a positive effect on (1) the amount of funding that start-ups attract and (2) the ability of start-ups to attract funding from formal investors and banks. In addition, our results provide evidence for the presence of a network broker mechanism, but not for the hit maker mechanism. Incubators may use these insights to better understand how they have a positive effect on the performance of start-ups. 


\section{Background}

\section{Incubators}

While incubators have been around since the 1950s, they became widespread in the 1980s. Over time, the concept has evolved considerably. Initially, incubators were seen as economic development tools for regions (Grimaldi and Grandi 2005). This first generation of incubators primarily offered basic services such as office space, facilities, and parking (Barrow 2001; Bruneel et al. 2012). In the 1980s, when it became clear that innovation and technology are important aspects of the economy, incubators found a new purpose in focusing on technology-based start-ups (Bruneel et al. 2012; Schwartz and Hornych 2010). It also became evident that a lack of business experience was an important barrier to start-up success. Hence, the second generation of incubators expanded their focus to facilitating organizational learning by offering professional consulting services, coaching, and mentoring (Bruneel et al. 2012). With the emergence of the IT sector and the Internet in the 1990s, the purpose of incubators shifted again. From having been a government-dominated phenomenon, private incubators started to emerge (Grimaldi and Grandi 2005). This third generation of incubators started to emphasize network services (Bruneel et al. 2012; Hansen et al. 2000; Lalkaka 2002). During recent years, the number of incubators grew substantially. Between 2007 and 2013, the number of incubators in Europe has increased approximately fivefold (Salido et al. 2013). In 2016, there were about 7000 incubators worldwide (InBIA 2016).

Despite the growth in incubators, there is still no consensus on the definition of an incubator (Aernoudt 2004; Bergek and Norrman 2008; Phan et al. 2005). The rapid growth of the incubator phenomenon has led to a great diversity in the incubator population, with incubators using different revenue models, providing different forms of support, and targeting different subgroups of start-ups (Vanderstraeten and Matthyssens 2012). However, there are still some baseline assumptions that can be made about contemporary incubators in Western Europe and North America. Hackett and Dilts (2004, p. 71) conclude that "[m]ost researchers agree that incubatorsincubation represent a systematic method of providing business assistance to firms in the early-stages of their development". So regardless of the ultimate purpose of the incubator, improving the performance of the accepted start-ups is the main direct aim of incubators.

The increasing popularity of incubators suggests that they are effective tools to help start-ups. Yet the empirical evidence for this is mixed. Some studies find that start-ups in incubators are more likely to survive, with 80 to $90 \%$ still in business after five years (European Commission 2002) or after leaving the incubator (Aernoudt 2004). Others find that incubators have a positive effect on start-ups' growth (Stokan et al. 2015). Yet "serious doubts have emerged about the general effectiveness of business incubation" (Tavoletti 2013, p. 423), since some find the incubator's impact on start-up performance indicators like growth in profit, sales, or employment to be almost nonexistent (Pena 2004; Tamásy 2007; Westhead and Storey 1994) or even negative when it comes to survival (Schwartz 2013). 


\section{Start-up performance}

The difference in results can partly be explained by the use of different measures for start-up performance. Typical performance measures for start-ups are employment growth, gross profit, business volume, survival, successful exit, goal attainment, evaluation of success by the founder, completion of idea or planning phase, and the size of investments raised (see Eveleens et al. 2016 for an overview). Given that we are examining early-stage start-ups, most of these measures are not applicable. For example, many early-stage start-ups have not recorded any sales or profit, hired employees, or made a successful exit. Measures like goal attainment or evaluation of success by founders are subjective and at risk of psychological biases (Richard et al. 2009).

\section{Investment size}

We use investment size as an applicable performance measure. Early-stage start-ups often require substantial amounts of funding to finance costly research and development prior to making sales (Westhead and Storey 1997). Raising funds from external stakeholders is considered to be an important milestone in the start-up's development, as it is a signal of viability (De Clercq et al. 2006; Rothaermel and Thursby 2005; Vohora et al. 2004). Consequently, the amount of investment raised is a commonly used measure in studies that explore the performance of technology-based start-ups (see e.g. Batjargal 2007; Shane and Stuart 2002) or incubators (see e.g. Radojevich-Kelley and Hoffman 2012; Rothaermel and Thursby 2005).

\section{Funding sources}

Investments can be raised from several sources (Cassar 2004). Incubators often encourage start-ups to attract venture capital from investors, as these are more likely to invest in high-risk ventures like start-ups, and can offer valuable advice (De Clercq et al. 2006). Consequently, investors ask for high returns on their investment, and often demand shares of the company or some form of control (Hellmann 1998). Possible alternative funding sources are government subsidies, which are usually focused on R\&D (Van Rijnsoever et al. 2014). Examples are the European Framework Programs and the Small Business and Innovation Research program in the United States. A third source of funding are banks. These provide loans, and are often risk averse, preferring physical assets to secure the loan in case of bankruptcy (Hall 2002). Fourth, crowdfunding is "an initiative undertaken to raise money for a new project proposed by someone, by collecting small-to-medium-size investments from several other people" (Ordanini et al. 2011, p. 444). Two more informal funding sources are "friends, family and fools" (Kotha and George 2012), and own investments. The alternative sources are often less preferred by incubators. We take them into consideration as they might fit the strategy of entrepreneurs who do not wish to give up equity to investors (Wasserman 2008).

\section{Incubation}

There is a broad variety of services that incubators can offer, depending on the goal of the incubator (Bergek and Norrman 2008; Schwartz and Hornych 2008), and 
conditions in the surrounding entrepreneurial ecosystem (Spigel 2015; Steinz et al. 2015; Van Weele et al. 2016b). Incubator services include, but are not limited to, shared equipment, seed capital, coaching, training to develop business skills, organization of networking events, access to professional service providers (e.g. legal), and access to providers of venture capital (Bøllingtoft and Ulhøi 2005; Bruneel et al. 2012; Soetanto and Jack 2013).

Scholars have started to categorize these services according to their anticipated outcome (Ahmad 2014; Amezcua et al. 2013; Bruneel et al. 2012). By doing so, the field moved toward understanding the mechanisms that explain how these services affect start-up performance. This can help to explain the contradictory empirical evidence for the benefits of incubation. The literature identifies two distinct theoretical mechanisms that explain the incubator's impact on start-up performance: direct support and networking (Amezcua et al. 2013; Bergek and Norrman 2008; Patton 2013).

\section{Direct support}

Direct support stems from the first and second generation of incubators. It refers to the provision of tangible and intangible resources from the incubator to the start-up (Amezcua and Grimes 2013; Van Weele et al. 2016a). Direct support is offered in the form of tangible resources like office space, shared equipment, or funding. It also includes the transfer of intangible resources such as business knowledge, which is transferred with the help of experienced incubator managers; pitching training sessions; and workshops. This helps start-ups to focus on the development of their business (Patton and Marlow 2011) and enables them to develop stronger, more convincing business propositions (Patton 2013; Rice 2002; Van Weele et al. 2016a). The result is better startup performance. As such, this mechanism portrays incubators as "hit makers".

\section{Networking}

The networking mechanism is an important trait of the third generation of incubators. It refers to the activities of incubators to improve a start-up's network (Bøllingtoft and Ulhøi 2005; Collinson and Gregson 2003; Warren et al. 2009). Incubators using this mechanism are providing referrals or organizing networking events. Through these services, start-ups are more visible, more aligned, and better connected to important actors external to the incubator, such as investors or banks (Bøllingtoft and Ulhøi 2005; Hansen et al. 2000). The affiliation with an established, reputable incubator also contributes to the legitimacy of start-ups, which further helps start-ups to convince investors (Bøllingtoft and Ulhøi 2005; Rao et al. 2008). Accordingly, the social capital engendered in the incubator's networks can help start-ups gain access to resources that in turn help to improve performance (Davidsson and Honig 2003). This mechanism thus portrays the incubator as a "network broker".

\section{Methods}

Assessing the influence of incubation on the performance of start-ups is associated with a number of methodological challenges. First, there is a lack of comparable data on 
incubators and the performance of their portfolio start-ups because start-ups supported by incubators often are not required to report any financial statements, individual incubators use various performance measures, and incubators often do not publicly disclose their metrics (Bergek and Norrman 2008; Hackett and Dilts 2004; Schwartz 2013). Second, start-ups are screened prior to being admitted into the incubator (Aerts et al. 2007). This makes it difficult to disentangle the incubator's contribution from its selection mechanism. Third, many datasets focus on one specific region or country, which makes it difficult to generalize the findings to the incubator population in general (see e.g. Barbero et al. 2012; Colombo and Delmastro 2002; Schwartz 2013; Stokan et al. 2015).

To alleviate these problems, we rely on data from an international survey among entrepreneurs. This allows us to measure start-up performance and the necessary control variables directly across different countries. A possible weakness of this approach is that the data is self-reported. Therefore, we base the measurement in the questionnaire as much as possible on scales that have been successfully used in previous studies, such as the Global Entrepreneurship Monitor (Global Entrepreneurship Monitor 2015), and the Panel Study on Entrepreneurial Dynamics (Davidsson 2008). A second problem with survey data is that it is problematic to distinguish between cause and effect (Campbell and Stanley 1966). Investments can be raised prior to, during, and after incubation. However, the more investments a start-up raises, the less need it has to be incubated. We argue below how we use this insight to build a model in which the relationship between incubation and investments is plausibly causal.

\section{Data collection}

We collected data among 935 early-stage technology-based entrepreneurs. Data were collected via an online business-to-business panel of a large European marketing agency. A major challenge for any study that tries to collect data among founders of start-ups is that the "incidence rate" is very low when relying on random sampling (Davidsson 2008). For the countries that were targeted, the "Total Early-Stage Entrepreneurial Activity" (TEA), which measures the percentage of the adult population that is either a nascent entrepreneur or an owner-manager of a new business (Global Entrepreneurship Monitor 2015), is only between 5 and $13 \%$. Of these entrepreneurs, only a fraction are starting a technology-based start-up (Davidsson 2008). Therefore, we relied on quota sampling, with quota set by country. Moreover, given that founders of start-ups are more likely to be highly educated (Wadhwa et al. 2008), we chose to direct our sample toward higher educated individuals.

Respondents had to meet three criteria to participate in the questionnaire. First, respondents had to be actively starting a business which they would wholly or partially own. Second, respondents had to be starting a technology-based start-up, which was defined as a new firm whose business is based on the exploitation of technological know-how through the creation of new products and services (Bergek and Norrman 2015; Trimi and Berbegal-Mirabent 2012). Third, to weed out mature companies, respondents were screened out if their business had been paying salaries for more than two years. Appendix 1 shows in detail the criteria we used to include respondents in our sample. The selection of sectors was made according to the Eurostat classification based on NACE codes (Eurostat 2009; see Appendix 2). Respondents were surveyed in 
Western Europe and North America. We selected these areas because they have a high concentration of both technology-based start-ups and incubators (Aerts et al. 2007; WEF 2015). To increase the representativeness of our sample, we weighted cases from each country in accordance with the country's TEA in relation to its population. Appendix 3 shows the number of respondents and case weights per country. Although the United States had the largest number of respondents, the country was still underrepresented in the sample. Ireland was most overrepresented. The case weights correct for these differences.

The average age of the respondents ranged from 20 to 69 years (weighted mean $=37.72: \mathrm{SD}=8.74)$; a large majority $(74.9 \%)$ were male, and $70.7 \%$ had a university degree. These descriptive statistics are in line with previous studies on technology-based start-ups (Wadhwa et al. 2008). Respondents received a small monetary reward for their participation.

\section{Measurement}

We first discuss the dependent variables: investment size (monetary amount of investments) and funding sources. We then discuss incubation as our main independent variable, and the control variables. The latter were selected based on the criterion that they should be related to both the dependent and independent variables. Table 1 provides the exact levels of the investment size variable and its descriptive statistics. Table 2 provides the descriptive statistics for the remaining variables.

\section{Investment size}

The questionnaire asked how much money entrepreneurs' start-ups had raised, including the investments of the entrepreneur. Respondents could answer on a seven-point scale that ranged from "less than $\$ 1000$ " to "more than $\$ 500,000 "$ ". The scale was adjusted to the currency in the respondent's country of origin (Euro, US dollar, pound sterling or Swiss franc). The exact numbers are based on the currency exchange rates and rounded to an interpretable number.

As mentioned above, causality is a major challenge for determining the influence of incubation on attracting investments as both processes can occur simultaneously. The process of raising investments can also continue post-incubation. However, given that incubators tailor their support toward early-stage start-ups that have typically attracted no or only small amounts of investment (Aernoudt 2004; Bergek and Norrman 2008; Pauwels et al. 2015), it is unlikely that a start-up would go into an incubator after having raised a monetary large amount of investments. Therefore, we created a "large investment size" variable that only captures the investments worth more than $\$ 100,000$. All investments smaller than this number were coded as " 0 " while the remaining values were unchanged. We assume $\$ 100,000$ to be a reasonable cutoff value for the early-stage start-ups in our sample. However, our results also hold for the cutoff value at $\$ 200,000$.

\section{Funding sources}

The questionnaire asked respondents which sources their start-up had used to raise funds (with the percentage of respondents answering "yes" in parentheses): Investor 
Table 1 Descriptive statistics of investment size

\begin{tabular}{|c|c|c|}
\hline Item & Total investments & Response \\
\hline \multirow{8}{*}{$\begin{array}{l}\text { How much money did your } \\
\text { business raise (in total, } \\
\text { including your own investment)? }\end{array}$} & $\begin{array}{l}\text { Less than } € 1000 / \text { Less than } \$ 1000 / \\
\text { Less than } £ 749 / \text { Less than CHF } 1000\end{array}$ & $41(4.4 \%)$ \\
\hline & $\begin{array}{l}€ 1000-€ 9999 / \$ 1000-\$ 9999 / \\
£ 750-£ 7499 / \text { CHF } 1000-\text { CHF } 9999\end{array}$ & $95(10.1 \%)$ \\
\hline & $\begin{array}{l}€ 10,000-€ 49,999 / \$ 10,000-\$ 49,999 / \\
\quad £ 7500-£ 34,999 / \text { CHF } 10,000-\text { CHF } 49999\end{array}$ & $172(18.4 \%)$ \\
\hline & $\begin{array}{l}€ 50,000-€ 99,000 / \$ 50,000-\$ 99,000 / \\
\quad £ 35,000-£ 74,999 / \text { CHF } 50,000-\text { CHF } 99,000\end{array}$ & $194(20.8 \%)$ \\
\hline & $\begin{array}{l}€ 100,000-€ 249,999 / \$ 100,000-\$ 249,999 / \\
\quad £ 75,000 \$-£ 199,999 / \text { CHF } 100,000 \$- \\
\quad \text { CHF } 249999\end{array}$ & $209(22.3 \%)$ \\
\hline & $\begin{array}{l}€ 250,000-€ 499,999 / \$ 250,000-\$ 499,999 / \\
\quad £ 200,000-£ 349,999 / \text { CHF } 250,000-\text { CHF } 499999\end{array}$ & $120(12.8 \%)$ \\
\hline & $\begin{array}{l}\text { More than } € 500,000 \text { / More than } \$ 500,000 / \\
\text { More than } £ 350,000 \text { / More than CHF 500,000 }\end{array}$ & $47(5.0 \%)$ \\
\hline & No answer & $58(6.2 \%)$ \\
\hline
\end{tabular}

(23.6\%), Government subsidy (11.2\%), Bank loan (39.9\%), Crowdfunding (13.1\%), Friends and family (38.1\%), Own investment (47.0\%).

\section{Incubation}

Incubation is our main independent variable. Some authors make an explicit distinction between accelerators and incubators (see e.g. Cohen and Hochberg 2014; NESTA 2011). They do so because they see incubators as providers of office space and basic services, and accelerators as focusing on intangible services (e.g. mentoring and networking). However, modern incubators are not merely providers of shared office space, but organizations that provide a comprehensive range of support services (Aernoudt 2004; Bergek and Norrman 2008; Bruneel et al. 2012). These services include those that are also provided by accelerators, such as mentoring and networking. Further, there is great diversity among the models and definitions of both incubators (Aernoudt 2004; Bergek and Norrman 2008; Bruneel et al. 2012) and accelerators (see e.g. Brown and Mawson 2016; Pauwels et al. 2015). "Incubators" and "accelerators" are both seen as "umbrella terms" (Aernoudt 2004, p. 127; Pauwels et al. 2015, p. 1) that largely overlap (Bosma and Stam 2012). As in practice accelerators and modern incubators can be very similar, we do not make an explicit distinction.

The questionnaire asked respondents whether they were familiar with the concept of "incubators" and/or "accelerators" prior to participating in this study, and whether they were part of such a program at the time of the study or had been in the past. Based on this, we constructed a nominal incubation variable with four levels: 1) not familiar with incubators or accelerators $(43.8 \%) ; 2$ ) familiar with incubators or accelerators, but has never been part of a program $(31.9 \%)$; 3 ) currently part of an incubator or acceleration program $(15.1 \%)$; and 4 ) has been part of an incubator or acceleration program in the past $(9.2 \%)$. 
Table 2 Descriptive statistics

\begin{tabular}{lll}
\hline & & Descriptive statistic \\
\hline 1 & Investment size & Median $=€ 50,000-€ 99,000$ \\
2 & Large investment size & Median $=$ less than $€ 100,000$ \\
3 & Not familiar, never been part & $43.8 \%$ \\
4 & Familiar, but never been part & $31.9 \%$ \\
5 & Currently part & $15.1 \%$ \\
6 & Have been part & $9.2 \%$ \\
7 & Team size & Mean $=3.65, \mathrm{SD}=2.41$ \\
8 & Start-up maturity & Mean $=4.35, \mathrm{SD}=3.00$ \\
9 & Industry experience & Mean $=8.97, \mathrm{SD}=6.90$ \\
10 & Entrepreneurial experience & Mean $=0.23, \mathrm{SD}=0.71$ \\
11 & Age & Mean $=37.72, \mathrm{SD}=8.74$ \\
12 & Gender (Female) & $25.1 \%$ \\
13 & Subsidy & $11.2 \%$ \\
14 & Loan & $39.9 \%$ \\
15 & Crowdfunding & $13.1 \%$ \\
16 & Investor & $23.6 \%$ \\
17 & Friends \& family & $38.1 \%$ \\
18 & Own investment & $47.0 \%$ \\
\hline
\end{tabular}

\section{Team size}

Larger teams of entrepreneurs may have more time to dedicate to the start-up, more technical and business experience, and a larger network. Having more team members also increases the team's ability to generate and develop ideas (Ruef 2002). Larger startup teams may thus establish more successful businesses than single founders or smaller teams (Chandler and Hanks 1994; Roberts 1991), and, consequently, raise more money. Larger teams also have more "mouths to feed", which further increases the need to raise external investments (Klepper 2001). We also expect a relationship between team size and incubation. The start-up team is an important selection criterion for incubators (Aerts et al. 2007; Bergek and Norrman 2008; Pauwels et al. 2015) and incubators pay close attention to the team's size. Incubators are typically hesitant to take on start-ups with single founders, but also have an aversion against teams that are too large (NESTA 2014; Pauwels et al. 2015) due to the difficulties associated with managing a large startup team (Curral et al. 2001). Team size was measured as the number of people in the business's founding team.

\section{Start-up maturity}

Start-ups grow and mature over time. This is commonly measured by gestation activities that entrepreneurs engage in while establishing a business (Dombrovsky et al. 2011; Liao and Welsch 2008). These activities can take place prior to, during, and after incubation. Incubators typically support start-ups in early phases (Bergek and 
Norrman 2008), but incubators often do expect a minimum level of maturity prior to being admitted. Start-ups that are more developed can also be expected to be more active in seeking funds and to need more investments. Liao and Welsch (2008) identified 26 gestation activities. To avoid respondent fatigue, the questionnaire asked in which of the following 12 activities the start-up engaged in during the last 12 months: 1) Formally registering the business; 2) Preparing a written business plan; 3) Organizing a start-up team; 4) Devoting themselves full-time to the business (more than $35 \mathrm{~h}$ per week); 5) Developing a proof of concept or working prototype; 6) Applying for a patent/copyright/trademark; 7) Defining market opportunities; 8) Hiring employees; 9) Asking financial institutions or other people for funds; 10) Receiving money from the sale of goods or services; 11) Purchasing materials, equipment, facilities, or other tangible goods for the business; 12) Discussing the new business's product or service with potential customers. The total number of activities was used as this variable.

\section{Industry experience}

Entrepreneurs with more experience in the industry of their start-up are more likely to have access to resources, technical experience, and business experience, as well as have a larger network and more credibility (Bosma et al. 2004; Cooper et al. 1994). Start-ups founded by entrepreneurs with extensive industry experience may be more attractive to incubators, and these start-ups may be more successful in fundraising. This variable was measured as the number of years the respondent had worked in the start-up's primary industry (Mitchell and Shepherd 2010).

\section{Entrepreneurial experience}

Entrepreneurs who have founded a start-up before likely have more business experience and a larger network than start-up founders with no entrepreneurial experience (Colombo and Grilli 2005; Dahlqvist et al. 2000). Entrepreneurs in incubators tend to be first-time entrepreneurs (Patton 2013; Rice 2002), as experienced entrepreneurs have less need of the incubator's services. Experienced entrepreneurs may also be more successful in fundraising. This variable was measured as the total number of businesses in which the respondent was directly involved during the start-up phase.

Age

During the course of a career, people have the opportunity to increase income and save up money. Consequently, older people have more money available than younger people, which they can use to invest in their own business. This reduces the initial need to seek investments. Younger entrepreneurs likely have less resources, less business experience, and a smaller business network. This might motivate them to join an incubator more than older entrepreneurs. For this reason, we include age as a control variable.

\section{Gender}

Gender and entrepreneurship is a heavily studied topic (Poggesi et al. 2015). Technology-based entrepreneurship and incubators can be seen as "masculine" 
environments in which women are more likely at a disadvantage (Marlow and McAdam 2012; Marlow and McAdam 2015). This is partly expressed by the use of investments as performance measure. Attracting investment is typically more difficult for women entrepreneurs, as investors tend to be biased toward funding men (Poggesi et al. 2015).

\section{Sector and country}

As financial demands, regulations, start-up support by incubators and entry requirements vary by sector (Malerba 2002), we coded a dummy for each sector. Regulations, finance opportunities, required investment sizes, and start-up support also vary per country (Ács et al. 2014; Singer et al. 2015), so we coded dummies for countries as well. See Appendices 2 and 3 for the descriptive statistics.

\section{Analysis}

We fitted a series of ordinal and binary logit models. In the ordinal logit models, investment size and large investment size are the dependent variables. The first step only enters the control variables. The second step adds the four-level incubation variable and the funding sources as independent variables. In the third step, interaction effects between the incubation variable and the use of funding sources are added, which tests whether incubated entrepreneurs tend to raise more funding from a particular source than non-incubated entrepreneurs. In the binary logit models, the six types of funding sources are the dependent variables. The first step enters the control variables, and the second step adds the incubation variable to the model. For all models, we used a chi-square test to assess whether each step improved the model. As a model performance indicator, we report the pseudo $\mathrm{R}^{2}$ by McFadden (1974). Appendix 4 presents the full correlation matrix.

To test if incubators are network brokers, hit makers, or both, we apply the following reasoning. If incubation has a positive relationship with specific funding sources and these funding sources contribute to investment size, then this is evidence that incubators support start-ups in gaining funding from these sources. This would mean that incubators serve as network brokers. However, this does not mean that incubated entrepreneurs gain more funding from a source than a non-incubated entrepreneur who uses the same source. If the interaction effect between incubation and specific funding sources is positively and significant, this means that incubated entrepreneurs gain more funding from a source than non-incubated entrepreneurs. This implies that incubators are hit makers.

\section{Results}

Table 3 presents the results of the ordinal logit models predicting investment size and large investment size. The McFadden $\mathrm{R}^{2}$ values range between 0.1 and 0.18 , which are reasonable model fits. The addition of the incubation and the funding source variables leads to a significant model improvement, as do the interaction effects. 


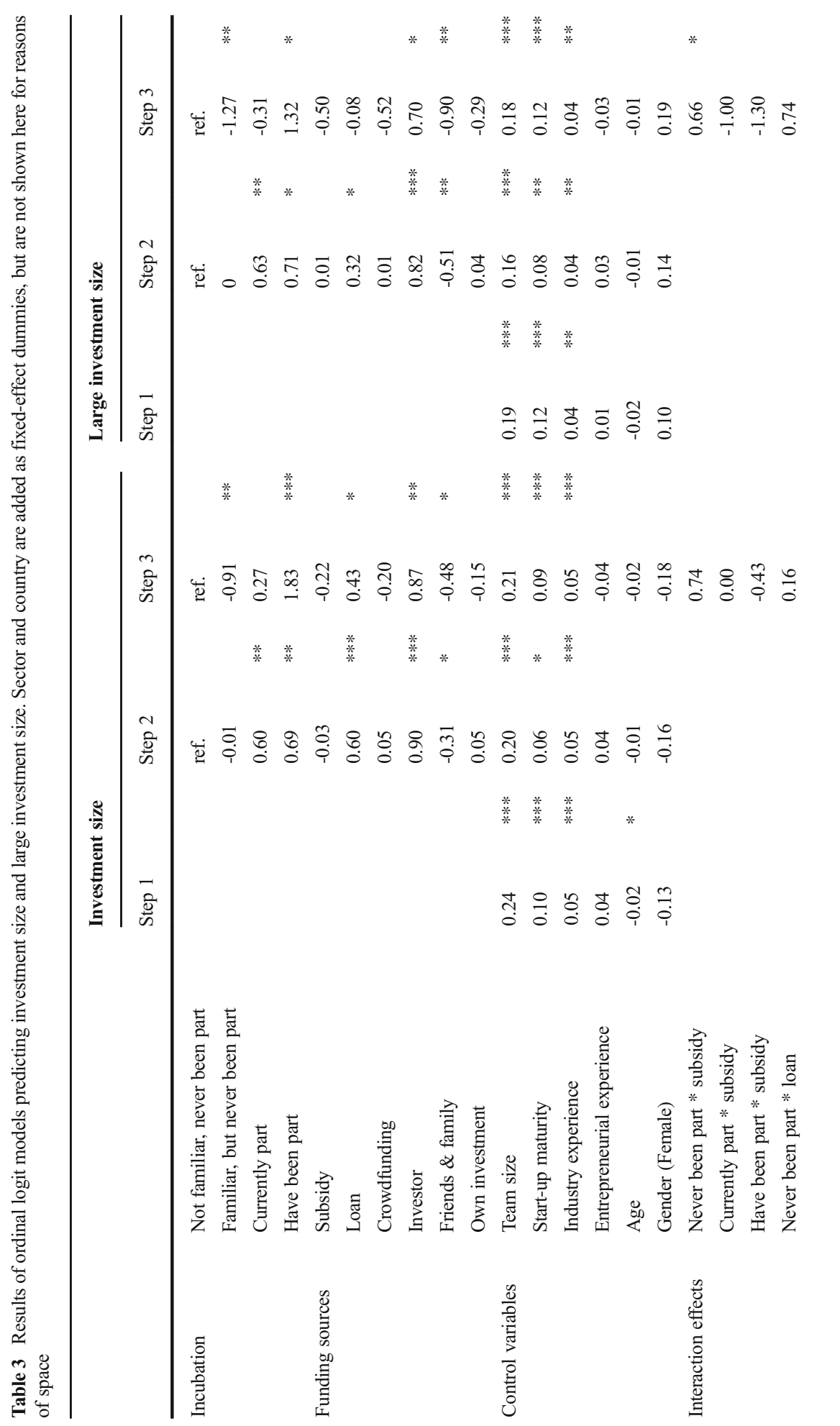




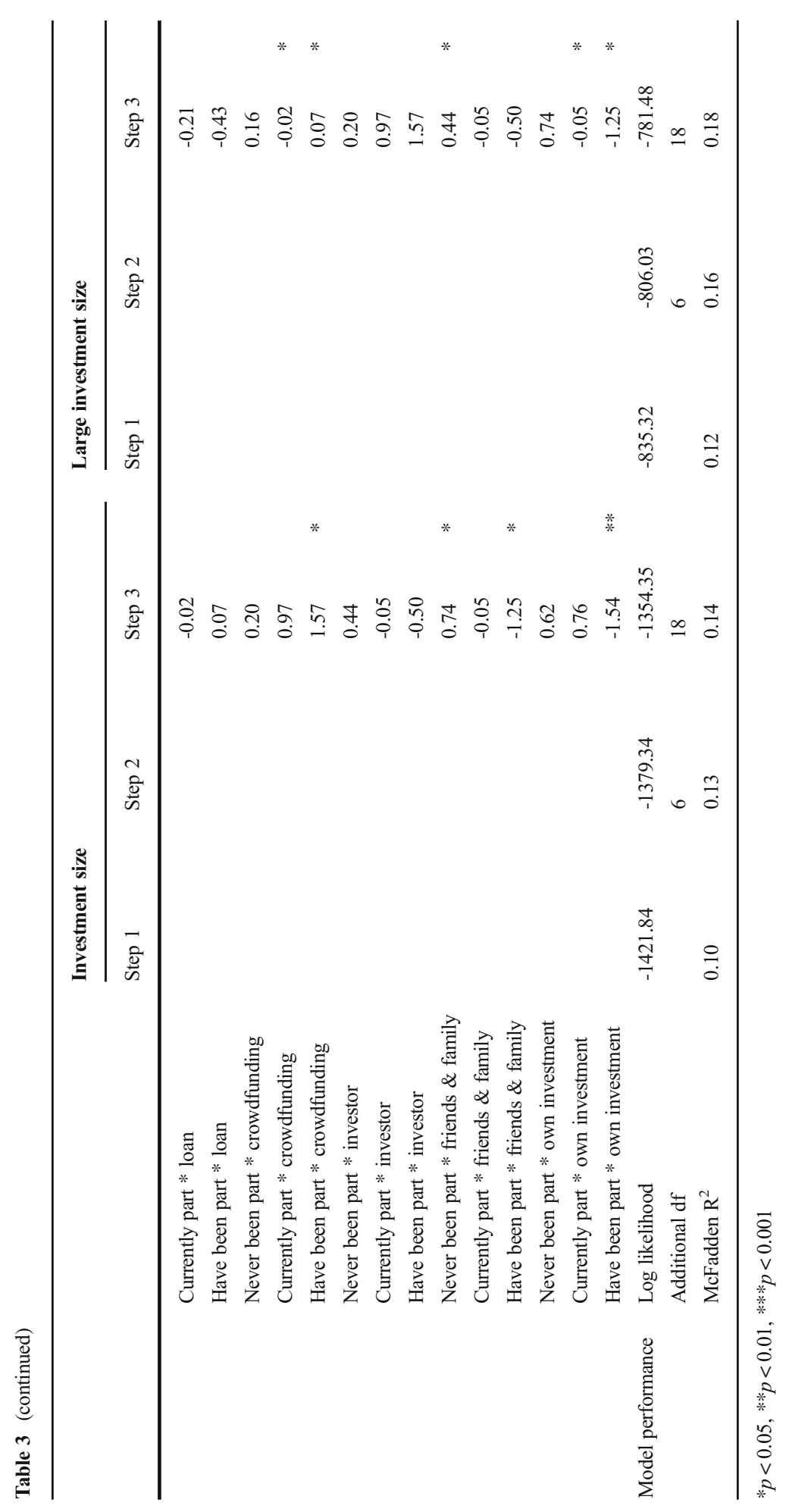




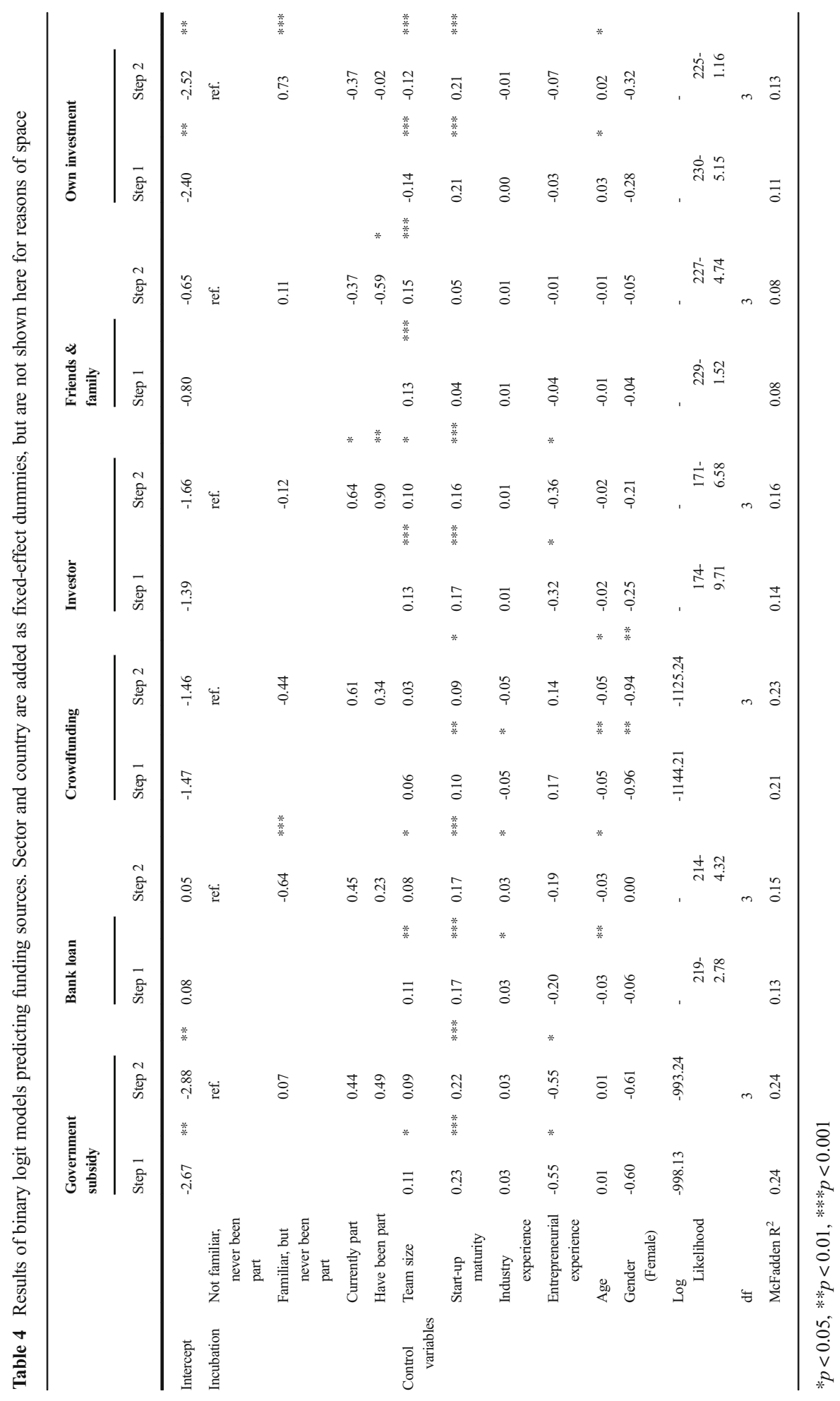


The models for investment size and large investment size are very similar. Step two reveals that in both instances being part of an incubator, or having been part of an incubator, has a positive effect on the size of investments. The second step also shows that the size of the investments is primarily positively associated with bank loans and investments, and negatively associated with friends and family. The interactions in step three between incubation and bank loans or investors are not significant. This means that incubated entrepreneurs do not get more funding from these sources than non-incubated entrepreneurs who use the same sources. Having been part of an incubator in the past in combination with crowdfunding is associated with more investments and more large investments, while currently being part of an incubator in combination with crowdfunding is only associated with more investments. ${ }^{1}$ It is worth noting that having been part of an incubator in the past combined with using friends and family or own investments is associated with lower investments. Being familiar with an incubator, but not being a part of one, in combination with using government subsidies, investments from friends and family, and own investments leads to more investments. Finally, the control variables show that team size, start-up maturity, and industry experience are all positively related to investment size, while entrepreneurial experience, age, and gender are not significant.

Table 4 presents the results of binary logit models predicting use of funding sources. The McFadden $\mathrm{R}^{2}$ values range between 0.11 and 0.24 , indicating reasonable to good model fits. The addition of the incubation variable significantly improves model fits for all funding sources except for government subsidies.

Compared to the reference category (not familiar with incubators and never been part of an incubator), entrepreneurs who are familiar with an incubator program, but who are currently not part of an incubator, are least likely to make use of bank loans. There are no significant differences between the other categories of incubation and making use of bank loans, nor are there any effects for crowdfunding. However, entrepreneurs who are or have been part of an incubator are more likely to use investors than those who have never been part of an incubator. Friends and family are used less by entrepreneurs who were part of an incubator in the past, while entrepreneurs who are familiar with incubators, but not a part of one, are more likely to use their own investments.

It is noteworthy that larger teams use more of all kinds of funding sources except crowdfunding (no effect) and own investments (negative effect). Start-up maturity is positively related to all funding sources except for friends and family. Industry experience is positively related to loans only, while entrepreneurial experience has small negative effects on using government subsidies and investors. Younger entrepreneurs are more likely to seek loans and crowdfunding for their business. As expected, older entrepreneurs make more use of their own investments. Finally, women entrepreneurs are less likely to use crowdfunding than their male counterparts.

\section{Discussion}

Our results show that incubation is associated with larger investments, and that incubation is positively associated with using loans and investors as funding sources.

\footnotetext{
${ }^{1}$ Being part of an incubator in combination with crowdfunding is positively associated with investments at the $10 \%$ level.
} 
These two sources are also associated with the largest investment sizes. The nonsignificant interaction effect means that there is no evidence that incubated start-ups raise more investments than non-incubated start-ups from these sources. The incubator provides access to investors and banks, but a non-incubated start-up who has access to these sources raises as much funding from these sources as incubated start-ups. This suggests that incubators serve as network brokers, but not as hit makers.

Also, entrepreneurs who are familiar with incubation but who have not been part of an incubator rely more on own funding or their friends and family, as well as government subsidies for large investments. This finding is consistent with the argument about network brokerage. Non-incubated entrepreneurs do not have access to sources like banks or investors, and are thus forced to find alternative funding sources.

This study suffers from a number of limitations. First, we associated the two mechanisms for performance with incubation services based on prior literature. However, the questionnaire did not measure these services directly, which means that we did not fully take into account heterogeneity among incubators, nor were we able to differentiate between quality of the services offered. Our results only apply to contemporary incubation in general. Future research should study how the type and quality of services are associated with performance. Second, to ensure anonymity and ease of filling out the questionnaire, it did not measure the investments per funding source directly. This could have resulted in a finer grained image of relationships studied. However, this likely would have led to a lower response and less reliable measurements. Third, we did not include two control variables that potentially further explain investments or being selected by an incubator: the quality of the product idea and the quality of the start-up team (Bergek and Norrman 2008). Both variables are difficult to measure in a reliable manner through a questionnaire. We encourage future studies to explore the characteristics of each start-up's team in more detail, for example by looking at the team's composition in terms of competences, background, ambitions, and networks.

\section{Conclusions}

The incubation literature has provided conflicting evidence on the impact of business incubation. Studies have reported positive (Aernoudt 2004; European Commission 2002; Stokan et al. 2015), negative (Schwartz 2008, 2013), or no effects (Pena 2004; Tamásy 2007; Westhead and Storey 1994) on various performance measures. Our study provides evidence for a positive effect of incubation on investments. This study also assessed two different mechanisms that can explain the effect of incubation (Amezcua et al. 2013; Bergek and Norrman 2008; Patton 2013). Thereby it helps to fill the gap in the literature of how incubators influence start-up performance (Ahmad 2014; Hackett and Dilts 2004). The results show that the prime value of an incubator for raising investments lies in its ability to connect start-ups to specific funding sources. Services like referrals and network events, or the sheer fact of being connected to a reputable incubator, give start-ups an important advantage. Our results also indicate that, in general, supporting activities directly aimed at gaining more investments (such as pitching training) have limited effect. This does not mean that supporting activities associated with hit-making — such as coaching, mentoring, or workshops - are all in vain. Raising investments is only one performance measure that is primarily applicable 
to early-stage start-ups (Eveleens et al. 2016). As start-ups mature, they need to eventually become profitable to return these investments. This is when conventional performance measures such as turnover, profit, and survival become important. It is quite possible that the hit-making support activities do have a positive influence on these kinds of performance measures, but this is an area for further research. Also, it is possible that some incubators offer these activities with such a high quality that they form an exception to the rule. However, in general, we conclude that incubators serve as network brokers and not as hit makers.

Acknowledgments The authors are grateful to Ellen Moors for her valuable comments.

\section{Compliance with Ethical Standards}

Funding statement This work was supported by the EU Climate-KIC program of the European Institute for Innovation and Technology.

Open Access This article is distributed under the terms of the Creative Commons Attribution 4.0 International License (http://creativecommons.org/licenses/by/4.0/), which permits unrestricted use, distribution, and reproduction in any medium, provided you give appropriate credit to the original author(s) and the source, provide a link to the Creative Commons license, and indicate if changes were made.

\section{Appendix 1}

\section{Selection questions for respondents}

1. Are you, alone or with others, currently trying to start a new business? This includes any selfemployment or selling of goods or services to others.

- No Not included in sample

- Yes

2. Would you consider the new business to be a technology-based start-up?

A technology-based start-up is a new firm whose business is based on the exploitation of technological knowhow through the creation of new products and services. Examples include the development of a new drug or software service.

- No Not included in sample

- Yes

3. In the past 12 months, in which of the following activities have you engaged during the development of your business?

Tick all that apply:

- Formally registering the business

- $\quad$ Preparing a written business plan

- $\quad$ Organizing a start-up team 
- Devoting yourself full-time to the business (more than $35 \mathrm{~h}$ per week)

- Developing a proof of concept or working prototype

- Applying for a patent/copyright/trademark

- Defining market opportunities

- Hiring employees

- Asking financial institutions or other people for funds

- Receiving money from the sales of goods or services

- Purchasing materials, equipment, facilities, or other tangible goods for the business

- Discussing the new business's product or service with potential customers

- None of the above: Not included in sample

4. Has the new business paid any salaries, wages, or payments in kind, including your own?

"Payments in kind" refers to goods or services provided as payments for work rather than cash. Payments in kind do not include stock options.

- No $^{-}$

- Yes

\section{If previous question was answered "Yes":}

5. For how long has the new business been paying salaries, wages, or payments in kind, including your own?

- $\quad$ For 0 to 3 months

- $\quad$ For 3 to 6 months

- For 6 to 12 months

- For 1 to 2 years

- For 3 to 5 years Not included in sample

- For more than 5 years Not included in sample

6. Do you, or will you, personally own all, part, or none of this business?

- All

- Part

- $\quad$ None Not included in sample

7. Is or will the new business be a subsidiary?

A subsidiary is a venture of which another organization owns more than $50 \%$ of voting shares.

- No, the new venture is not the subsidiary of another organization

- Yes, the new venture is a subsidiary of another organization Not included in sample 


\section{Appendix 2: Respondents by sector}

Table 5 Respondents by sector

Sector

Sample respondents

Aerospace

Artificial Intelligence

Basic metals

Biotechnology \& pharmaceuticals

Chemistry

Clean technology

Coke and petroleum products

Electrical engineering \& equipment

Energy

Fabricated metal products

Functional or processed food

ICT \& computers

Information systems

Machinery

Medical \& dental instruments

Motor vehicles

Nanotechnology

Optical products

Other non-metallic mineral products

Photonics

Repair \& installation machinery

Reproduction recorded media

Robotics

Rubber and plastic products

Ships and boats

Telecommunications

Transport

Transport equipment

Water

Weapons \& ammunition

Other, please specify: 


\section{Appendix 3: Respondents and case weights per country}

Table 6 Respondents and case weights per country

\begin{tabular}{llllll}
\hline Country & $\begin{array}{l}\text { Total early-stage } \\
\text { entrepreneurial } \\
\text { activity }\end{array}$ & $\begin{array}{l}\text { Country } \\
\text { population size }\end{array}$ & $\begin{array}{l}\text { Population of total } \\
\text { early-stage } \\
\text { entrepreneurs }\end{array}$ & $\begin{array}{l}\text { Sample } \\
\text { respondents }\end{array}$ & $\begin{array}{l}\text { Case } \\
\text { Weight }\end{array}$ \\
\hline Austria & 8.71 & $8,623,073$ & 751,070 & 37 & 0.280 \\
Canada & 13.04 & $35,851,774$ & $4,675,071$ & 109 & 0.592 \\
Belgium & 5.4 & $11,267,581$ & 608,449 & 38 & 0.221 \\
France & 5.34 & $67,107,000$ & $3,583,514$ & 125 & 0.395 \\
Germany & 5.27 & $81,197,500$ & $4,279,108$ & 125 & 0.472 \\
Ireland & 6.53 & $4,635,400$ & 302,692 & 65 & 0.064 \\
Netherlands & 9.46 & $16,928,000$ & $1,601,389$ & 67 & 0.330 \\
Switzerland & 7.12 & $8,279,700$ & 589,515 & 24 & 0.339 \\
United Kingdom & 10.66 & $64,800,000$ & $6,907,680$ & 104 & 0.916 \\
United States of America & 13.81 & $322,210,000$ & $44,497,201$ & 241 & 2.546 \\
\hline
\end{tabular}




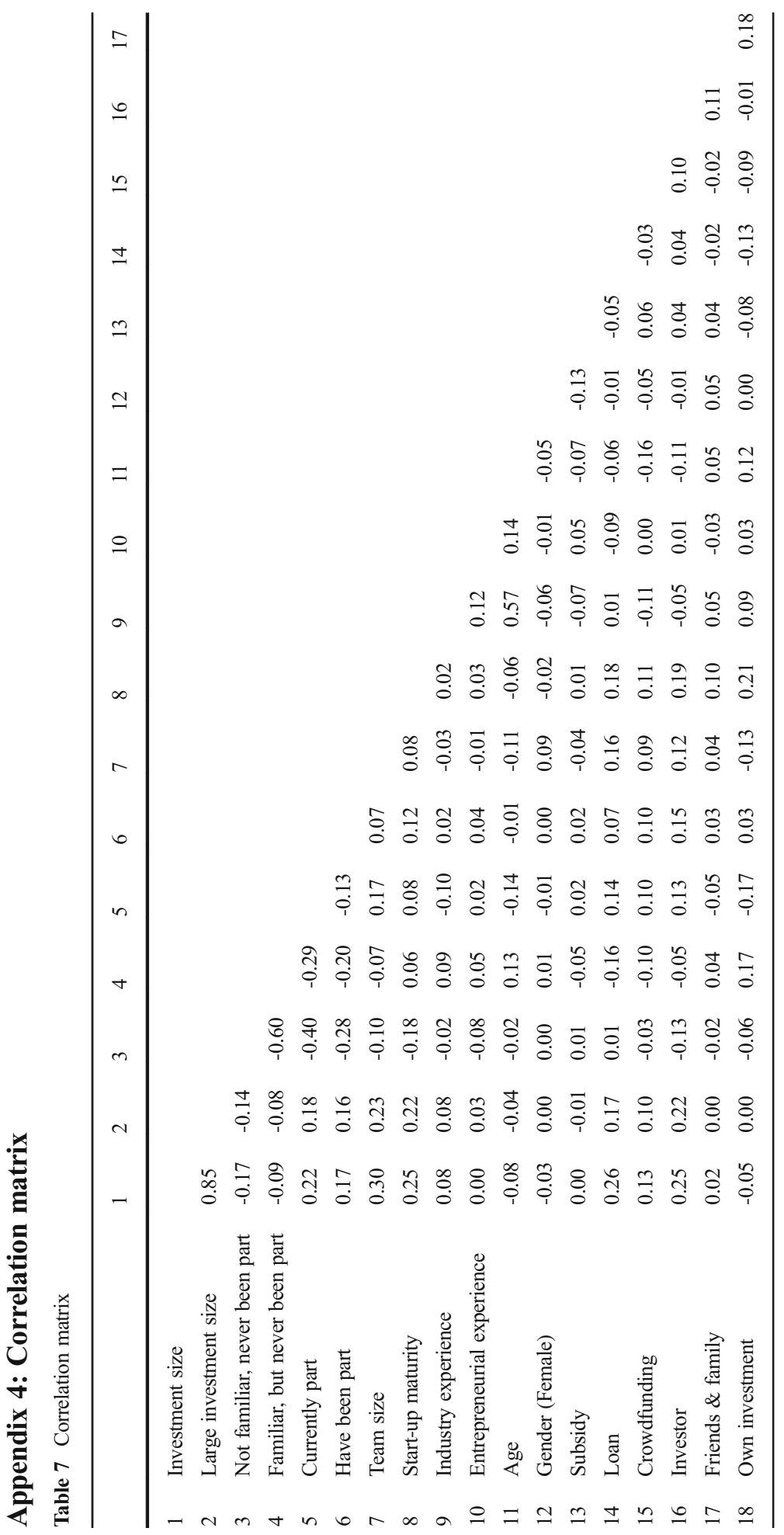




\section{References}

Ács, Z. J., Autio, E., \& Szerb, L. (2014). National Systems of Entrepreneurship: Measurement issues and policy implications. Research Policy, 43, 476-494. doi:10.1016/j.respol.2013.08.016.

Aernoudt, R. (2004). Incubators: tool for entrepreneurship? Small Business Economics, 23, 127-135.

Aerts, K., Matthyssens, P., \& Vandenbempt, K. (2007). Critical role and screening practices of European business incubators. Technovation, 27, 254-267. doi:10.1016/j.technovation.2006.12.002.

Ahmad, A. (2014). A mechanisms-driven theory of business incubation. International Journal of Entrepreneurial Behaviour \& Research, 20, 375-405. doi:10.1108/IJEBR-11-2012-0133.

Ahmad, A., Ingle, S., 2013. Business Incubators and HTSF Development: Setting an Agenda for Further Research, in: Oakey, R., Groen, A., Cook, C., Van Der Sijde, P. (Eds.), New Technology-Based Firms in the New Millenium, Volume 10. Emerald Group Publishing Limited, Bingley, pp. 119-140.

Amezcua, A., \& Grimes, M. (2013). Organizational Sponsorship and Founding Environments: A Contingency View on the Survival of Business Incubated Firms, 1994-2007. Academy of Management, 56, 1-29.

Amezcua, A. S., Grimes, M. G., Bradley, S. W., \& Wiklund, J. (2013). Organizational sponsorship and founding environments: A Contingency view on the survival of business-incubated firms, 1994-2007. Academy of Management Journal, 56, 1628-1654. doi:10.5465/amj.2011.0652.

Barbero, J. L., Casillas, J. C., Ramos, A., \& Guitar, S. (2012). Revisiting incubation performance. Technological Forecasting and Social Change, 79, 888-902. doi:10.1016/j.techfore.2011.12.003.

Barrow, C., 2001. Incubators: a realist's guide to the world's new business accelerators. UK.

Batjargal, B. (2007). Internet entrepreneurship: Social capital, human capital, and performance of Internet ventures in China. Research Policy, 36, 605-618. doi:10.1016/j.respol.2006.09.029.

Bergek, A., \& Norrman, C. (2008). Incubator best practice: A framework. Technovation, 28, 20-28. doi:10. 1016/j.technovation.2007.07.008.

Bergek, A., \& Norrman, C. (2015). Integrating the supply and demand sides of public support to NTBFs: a typology with implications for policy makers. Science and Public Policy, 42. doi:10.1093/scipol/scu072.

Bøllingtoft, A., \& Ulhøi, J. P. (2005). The networked business incubator-leveraging entrepreneurial agency? Journal of Business Venturing, 20, 265-290. doi:10.1016/j.jbusvent.2003.12.005.

Bosma, N., Stam, E., 2012. Local Policies for High-Employment Growth Enterprises.

Bosma, N., van Praag, M., Thurik, R., \& de Wit, G. (2004). The Value of Human and Social Capital Investments for the Business Performance of Startups. Small Business Economics, 23, 227-236. doi:10. 1023/B:SBEJ.0000032032.21192.72.

Brown, R., \& Mawson, S. (2016). Targeted support for high growth firms: Theoretical constraints, unintended consequences and future policy challenges. Environment and Planning C: Government and Policy 34, 816-836. doi:10.1177/0263774X15614680.

Bruneel, J., Ratinho, T., Clarysse, B., \& Groen, A. (2012). The Evolution of Business Incubators: Comparing demand and supply of business incubation services across different incubator generations. Technovation, 32, 110-121. doi:10.1016/j.technovation.2011.11.003.

Campbell, D. T., \& Stanley, J. C. (1966). Experimental and Quasi-Experimental Designs for Research. London: Houghton Mifflin Company.

Cassar, G. (2004). The financing of business start-ups. Journal of Business Venturing, 19, 261-283.

Chandler, G., \& Hanks, S. (1994). Founder competence, the environment and venture performance. Entrepreneurship. Theory and Practice, 18, 77-89.

Cohen, S., \& Hochberg, Y. V. (2014). Accelerating Startups: The Seed Accelerator Phenomenon. SSRN Electronic. Journal, 1-16. doi:10.2139/ssrn.2418000.

Collinson, S., \& Gregson, G. (2003). Knowledge networks for new technology-based firms: an international comparison of local entrepreneurship promotion. $R \& D$ MANAGEMENT, 33, 189-208. doi:10.1111/ 1467-9310.00292.

Colombo, M. G., \& Delmastro, M. (2002). How effective are technology incubators? Evidence from Italy. Research Policy, 31, 1103-1122. doi:10.1016/S0048-7333(01)00178-0.

Colombo, M. G., \& Grilli, L. (2005). Founders' human capital and the growth of new technology-based firms: A competence-based view. Research Policy, 34, 795-816. doi:10.1016/j.respol.2005.03.010.

Cooper, A. C., Gimeno-Gascón, F. J., \& Woo, C. Y. (1994). Initial Human and Financial Capital as Predictors of New Venture Performance. Journal of Business Venturing, 9, 371-395. doi:10.3905/jpe.1997.409668.

Curral, L. A., Forrester, R. H., Dawson, J. F., \& West, M. A. (2001). It's what you do and the way that you do it: Team task, team size, and innovation-related group processes. European Journal of Work and Organizational Psychology, 10, 187-204. 
Dahlqvist, J., Davidsson, P., \& Wiklund, J. (2000). Initial Conditions as Predictors of New Venture Performance: A Replication and Extension of the Cooper et al. study. Enterprise and Innovation Management Studies, 1, 1-17. doi:10.1080/146324400363491.

Davidsson, P. (2008). The Entrepreneurship Research Challenge. Cheltenham: Edward Elgar Publishing.

Davidsson, P., \& Honig, B. (2003). The role of social and human capital among nascent entrepreneurs. Journal of Business Venturing, 18, 301-331.

De Clercq, D., Fried, V. H., Lehtonen, O., \& Sapienza, H. J. (2006). An entrepreneur's guide to the venture capital galaxy. Academy of Management Perspectives, 20, 90-112. doi:10.5465/AMP.2006.21903483.

Dombrovsky, V., Paalzow, A., Rastrigina, O., 2011. Latvia: Panel Study of Entrepreneurial Dynamics Overview, in: Reynolds, P., Curtin, R. (Eds.), New Business Creation: An International Overview. Springer, New York, pp. 143-174.

European Commission (2002). Final report: benchmarking of Business Incubators. Sevenoaks. doi:10.1086/ 656690.

Eurostat, 2009. Aggregations of manufacturing based on NACE Rev 2.

Eveleens, C.P., Van Rijnsoever, F.J., Niesten, E. (2016). How network-based incubation helps start-up performance: a systematic review against the background of management theories. The Journal of Technology Transfer. doi:10.1007/s10961-016-9510-7.

Global Entrepreneurship Monitor, 2015. Key indicators [WWW Document].

Grimaldi, R., \& Grandi, A. (2005). Business incubators and new venture creation: an assessment of incubating models. Technovation, 25, 111-121.

Hackett, S. M., \& Dilts, D. M. (2004). A systematic review of business incubation research. The Journal of Technology Transfer, 29, 55-82.

Hall, B. H. (2002). The financing of research and development. Oxford Review of Economic Policy, 18, 35-51.

Hansen, M. T., Chesbrough, H. W., Nohria, N., \& Sull, D. N. (2000). Networked incubators. Hothouses of the new economy. Harvard business review, 78, 74-84.

Hellmann, T. (1998). The allocation of control rights in venture capital contracts. RAND Journal of Economics, 29, 57-76.

InBIA (2016). International Business Incubation Association [WWW Document]. URL: Business Incubation FAQs www.inbia.org (accessed.

Klepper, S. (2001). Employee startups in high-tech industries. Industrial and Corporate Change, 10, 639-674.

Kotha, R., \& George, G. (2012). Friends, family, or fools: Entrepreneur experience and its implications for equity distribution and resource mobilization. Journal of Business Venturing, 27, 525-543.

Lalkaka, R. (2002). Technology business incubators to help build an innovation-based economy. Journal of Change Management, 3, 167-176. doi:10.1080/714042533.

Liao, J., \& Welsch, H. (2008). Patterns of venture gestation process: Exploring the differences between tech and non-tech nascent entrepreneurs. The Journal of High Technology Management Research, 19, 103113. doi:10.1016/j.hitech.2008.10.003.

Malerba, F. (2002). Sectoral systems of innovation and production. Research Policy, 31, 247-264.

Marlow, S., \& McAdam, M. (2012). Analyzing the Influence of Gender Upon High-Technology Venturing Within the Context of Business Incubation. Entrepreneurship. Theory and Practice, 36, 655-676. doi:10. 1111/j.1540-6520.2010.00431.x.

Marlow, S., \& Mcadam, M. (2015). Incubation or Induction? Gendered Identity Work in the Context of Technology Business Incubation. Entrepreneurship: Theory and Practice, 791-816. doi:10.1111/etap. 12062.

McFadden, D. (1974). Conditional logit analysis of qualitative choice behavior. In P. Zarembka (Ed.), Frontiers in Economics (pp. 105-142). New York: Academic Press.

Mitchell, J. R., \& Shepherd, D. a. (2010). To thine own self be true: Images of self, images of opportunity, and entrepreneurial action. Journal of Business Venturing, 25, 138-154. doi:10.1016/j.jbusvent.2008.08.001.

NESTA (2011). The Startup Factories: The rise of accelerator programmes to support new technology ventures. London.

NESTA, 2014. Startup Accelerator Programmes: a practical guide 31.

Oakey, R. P. (2012). High-Technology Entrepreneurship. London and New York: Routledge.

Ordanini, A., Miceli, L., Pizzetti, M., \& Parasuraman, A. (2011). Crowd-funding: transforming customers into investors through innovative service platforms. Journal of Service Management, 22, 443-470.

Patton, D. (2013). Realising potential: The impact of business incubation on the absorptive capacity of new technology-based firms. International Small Business Journal. doi:10.1177/0266242613482134.

Patton, D., \& Marlow, S. (2011). University technology business incubators: helping new entrepreneurial firms to learn to grow. Environment and Planning. C, Government \& Policy, 29, 911-926. doi:10.1068/ c10198b. 
Pauwels, C., Clarysse, B., Wright, M., \& Hove, J. V. (2015). Understanding a new generation incubation model : The accelerator. Technovation. doi:10.1016/j.technovation.2015.09.003.

Pena, I. (2004). Business incubation centers and new firm growth in the Basque country. Small Business Economics, 23, 223-236.

Phan, P. H., Siegel, D. S., \& Wright, M. (2005). Science parks and incubators: observations, synthesis and future research. Journal of Business Venturing, 20, 165-182. doi:10.1016/j.jbusvent.2003.12.001.

Poggesi, S., Mari, M., \& De Vita, L. (2015). What's new in female entrepreneurship research? Answers from the literature. International Entrepreneurship and Management Journal, 1-30. doi:10.1007/s11365-015-0364-5.

Radojevich-Kelley, N., \& Hoffman, D. D. L. D. (2012). Analysis of Accelerator Companies: An Exploratory Case Study of Their Programs, Processes, and Early Results. Small Business Institute®. Journal, 8, 54-70.

Rao, R. S., Chandy, R. K., \& Prabhu, J. C. (2008). The Fruits of Legitimacy:Why Some New Ventures Gain More from Innovation Than Others. Journal of Marketing, 72, 58-75. doi:10.1509/jmkg.72.4.58.

Rice, M. P. (2002). Co-production of business assistance in business incubators: an exploratory study. Journal of Business Venturing, 17, 163-187. doi:10.1016/S0883-9026(00)00055-0.

Richard, P. J., Devinney, T. M., Yip, G. S., \& Johnson, G. (2009). Measuring Organizational. Performance: Towards Methodological Best Practice. Journal of Management. doi:10.1177/0149206308330560.

Roberts, E. (1991). High stakes for high-tech entrepreneurs: Understanding venture capital decision making. Sloan Management Review, 32, 9-20.

Rothaermel, F. T., \& Thursby, M. (2005). University-incubator firm knowledge flows: assessing their impact on incubator firm performance. Research Policy, 34, 305-320. doi:10.1016/j.respol.2004.11.006.

Ruef, M. (2002). Strong ties, weak ties and islands: structural and cultural predictors of organizational innovation. Industrial and Corporate Change, 11, 427-449. doi:10.1093/icc/11.3.427.

Salido, E., Sabás, M., Freixas, P., 2013. The Accelerator and Incubator Ecosystem in Europe.

Schwartz, M. (2008). Beyond incubation: an analysis of firm survival and exit dynamics in the post-graduation period. The Journal of Technology Transfer, 34, 403-421. doi:10.1007/s10961-008-9095-x.

Schwartz, M. (2013). A control group study of incubators' impact to promote firm survival. The Journal of Technology Transfer, 38, 302-331. doi:10.1007/s10961-012-9254-y.

Schwartz, M., \& Hornych, C. (2008). Specialization as strategy for business incubators: An assessment of the Central German Multimedia Center. Technovation, 28, 436-449. doi:10.1016/j.technovation.2008.02.003.

Schwartz, M., \& Hornych, C. (2010). Cooperation patterns of incubator firms and the impact of incubator specialization: Empirical evidence from Germany. Technovation, 30, 485-495. doi:10.1016/j. technovation.2010.05.001.

Shane, S., \& Stuart, T. (2002). Organizational Endowments and the Performance of University Start-ups. Management Science, 48, 154-170. doi:10.1287/mnsc.48.1.154.14280.

Singer, S., Amorós, J.E., Moska, D., 2015. Global entrepreneurship monitor 2014 [WWW Document]. Global Entrepreneurship Research Consortium, London, UK. URL http:/www.gemconsortium.org/data

Soetanto, D. P., \& Jack, S. L. (2013). Business incubators and the networks of technology-based firms. The Journal of Technology Transfer, 38, 432-453. doi:10.1007/s10961-011-9237-4.

Spigel, B., 2015. The Relational Organization of Entrepreneurial Ecosystems. Entrepreneurship Theory and Practice.

Steinz, H.J., Van Rijnsoever, F.J., Nauta, F., 2015. How to green the Red Dragon: A start-ups' little helper for sustainable development in China. Business Strategy and the Environment.

Stokan, E., Thompson, L., \& Mahu, R. J. (2015). Testing the Differential Effect of Business Incubators on Firm Growth. Economic Development Quarterly, 29, 317-327. doi:10.1177/0891242415597065.

Tamásy, C. (2007). Rethinking Technology-Oriented Business Incubators: Developing a Robust Policy Instrument for Entrepreneurship, Innovation, and Regional Development? Growth and Change, 38, 460-473. doi:10.1111/j.1468-2257.2007.00379.x.

Tavoletti, E. (2013). Business incubators: effective infrastructures or waste of public money? Looking for a theoretical framework, guidelines and criteria. Journal of the Knowledge Economy, 4, 423-443.

Trimi, S., \& Berbegal-Mirabent, J. (2012). Business model innovation in entrepreneurship. International Entrepreneurship and Management Journal, 8, 449-465. doi:10.1007/s11365-012-0234-3.

Van Rijnsoever, F. J., Welle, L., \& Bakker, S. (2014). Credibility and legitimacy in policy-driven innovation networks: Resource dependencies and expectations in Dutch electric vehicle subsidies. The Journal of Technology Transfer, 39, 635-661.

Van Weele, M. A., Van Rijnsoever, F. J., Eveleens, C. P., Steinz, H. J., \& Van Stijn, N. (2016a). Start-EU-up! International incubation practices to address the main challenges of the Western. The Journal of Technology Transfer: European entrepreneurial ecosystem, in press. 
Van Weele, M.A., van Rijnsoever, F.J., Nauta, F., (2016b) You can't always get what you want: how entrepreneur's perceived resource needs affect the incubator's assertiveness. Technovation. doi:10.1016/ j.technovation.2016.08.004.

Vanderstraeten, J., \& Matthyssens, P. (2012). Service-based differentiation strategies for business incubators: Exploring external and internal alignment. Technovation, 32, 656-670. doi:10.1016/j.technovation.2012. 09.002.

Vohora, A., Wright, M., \& Lockett, A. (2004). Critical junctures in the development of university high-tech spinout companies. Research Policy, 33, 147-175. doi:10.1016/S0048-7333(03)00107-0.

Wadhwa, V., Freeman, R., Rissing, B., 2008. Education and tech entrepreneurship.

Warren, L., Patton, D., \& Bream, D. (2009). Knowledge acquisition processes during the incubation of new high technology firms. International Entrepreneurship and Management Journal, 5, 481-495. doi:10. 1007/s11365-009-0121-8.

Wasserman, N. (2008). The founder's dilemma. Harvard Business Review, 86, 102-109.

WEF (2015). Leveraging Entrepreneurial Ambition and Innovation : A Global Perspective on Entrepreneurship. Davos: Competitiveness and Development.

Westhead, P., Storey, D., 1994. An assessment of firms located on and off science parks in the UK. London.

Westhead, P., \& Storey, D. J. D. (1997). Financial constraints on the growth of high technology small firms in the United Kingdom. Applied Financial Economics, 7, 197-201. 